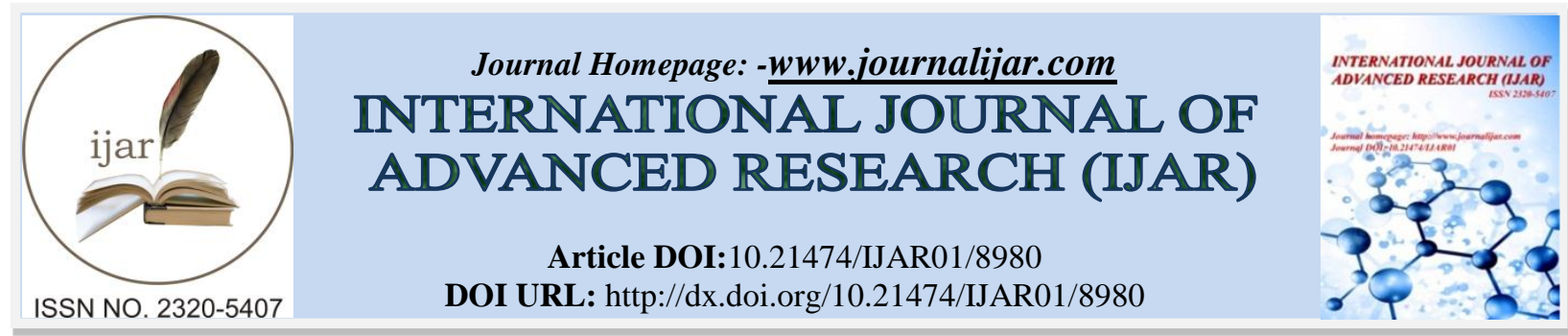

RESEARCH ARTICLE

\title{
INNOVATION AND DEVELOPMENT OF INFORMATION COMMUNICATION TECHNOLOGY (ICT) IN LIBRARIES: A NEW DIMENSION IN LIBRARIANSHIP.
}

\section{Dr. Naveed-e Sehar ${ }^{1}$ and Mahnoor Khan ${ }^{2}$.}

1. Asstt. Professor,Department of Library and Information Science, University of Karachi.

2. Asstt. Librarian, IBA Karachi.

\section{Manuscript Info}

Manuscript History

Received: 01 March 2019

Final Accepted: 03 April 2019

Published: May 2019

\section{Abstract}

Technology has become an essential necessity of the postmodern era. Every activity we indulge in has become far easier than it was thousands of tears before. Whether wish it or not there is a kind of thrust that is pushing us towards the adoption of these innovations' day by day. In library's environment its use was marked as milestone for data searching, access, correspondence and transfer of information thus reformed the traditional library trends. The study endeavors to identify various components of ICT which are used or being used in libraries and information centers Now the challenge for all types of libraries is to develop new strategies involving new alliance and partner hip to support print/ digital resources. Successful strategies will almost certainly demand all organizational change together with effective application of new information communication technologies.

Copy Right, IJAR, 2019,. All rights reserved.

\section{Introduction:-}

Modern technology of the $21^{\text {st }}$ century is the direct consequence of inquisitive minds and evolving scientific rationales. Constant changes coming in the world of technology have almost transformed the physical world into a digital world. Thus, it is justified to believe that we are living in the digital age where digital technology rules over physical lives. Although these technological changes are not the outcome of a sudden excursion but rather slow, step-by-step processes and changes taking place in the world of scientific experimentation. Lord Tennyson has remarkably commented on the nature of science:

"Science moves slowly creeping on from point to point." Science is the pillar of technology. It has provided strong foundations for technology which result in a great outburst of technological innovations everywhere across the globe.

Objective of the study: -

This study is Focused on following objectives.

1. To find out various components of ICT used in libraries

2. To hint the advancement in libraries.

3. To identify the reasons for introducing in libraries

4. To explicate the functions, impact and challenges of ICT based library services. 


\section{Materials and Methods: -}

This paper is constructed on the review of primary and secondary literature which includes, books, journals, documents paper and seminar papers. etc. relevant information was also gathered and consulted through Internet.

\section{Concept of Technology:-}

"Technology, like art, is a soaring exercise of the human mind."Daniel Bell.

"The great growling engine of change.........Technology" (Toffler, 1970)

The term 'technology' incorporates a vast meaning and concept. Generally, it refers to the processes by which humans' fashion their tools and machines to increase their control and understanding of the material environment. Thus, it involves the usage of tools which affects and controls the environment, but the concept varies according to the use it is being put to.

Technology, in ancient times, was defined by Homer and Hesiod as the spoken word of manual craft or cunning skill. Later by 330 B.C., Aristotle coined the Greek term 'technologia'; a combination of two Greek words, 'techno' that refers to art and craft, and 'logia' meaning an area of study. Thus, the term technology literally means the study or science of crafting.

In this way, it refers to the daily materials and objects commonly used such as machines, utensils, etc., crafted by humans to bring convenience to their daily chores and drudgery. From Natural to Social Sciences, and sports to Engineering, technology has been the source of constant development and built-up the modern world.

\section{Impact of Technology on Society:-}

Changes are the vital signs of life from the very inception. Human life is transforming from time to time: it started from Stone Age to Agriculture Age and later transformed to the Industrial Age. How it came to meet the electronic age, or Age of Information, remains an awe-inspiring speculation. Rapid developments have taken place since 1960s, which have provided new dimensions to human life.

"Science and technology have come to pervade every aspect of our lives and as a result, our society is changing at a speed which is quite unprecedented". (Khan,1995)

The emerging technology has great impact on everyday life. New electronic means and modes are introduced in society for effective working. Now, information technology is playing a vital role in business education and other fields of life.

The advent of latest, transformative technology has given new dimensions to the production, management and dissemination of information. Consequently, information is being more readily and rapidly produced and therefore, this age is also known as the Information Explosion Age. Information technology (IT) has been evolving since the latter half of the $20^{\text {th }}$ century, particularly since 1960 s and 1970s. It has revolutionized the media and modes of computing, storing and communicating information. The changes in the processing and distribution of information, made with enthusiasm and by necessity, have affected our society in many ways. The development of newest technology has greatly influenced the society, especially corporate organizations, in computing, storing and communicating data. As part of evolving society, organizations are compelled to stay abreast and operate innovatively with the latest technology for development, progress and inventiveness in their work in the contemporary domain.

Technological evolution has also greatly influenced the educational trends of societies globally. The rapid generation of information and access to it have provided new dimensions to learning and teaching methods. Educational institutions are adopting latest technology to update their teachers and students and enable them to compete at the international front. Thus, it is easy to claim that human beings are born to embrace evolution and in return, they step up to expand and enhance the evolution- technological, as the base form, to improve the quality of their lives and physical functions. 
"If the true role of information technology in a world context can be fully appreciated it will provide us with a powerful tool for the development of better environment. However, if its contribution is abused and misunderstood, we could find ourselves in a technological society we do not wish to see." (Adams, 1986)

\section{Core Constituent of ICT: -}

Patil, Kumbarand and Krishananda classified the core constituent of information Technology, which commonly used in libraries.

"ICT came about as a result of the digital conservation of computer technologies, telecommunication technologies and other media communication technologies. The components of Information Technology, which commonly used in library and information centers, are as under:

1. Computer Technology

2. communication Technology

3. Reprographic Technology

4. Micrographic and Printing technology" (Pradhan,2006)

(Rehman,2003) "stated that ICT is the fusion of two important technologies: electronics and communications. The brief account of these Information and Communication Technologies is discussed below:

\section{Computer Technology:-}

This technology can be divided into following categories -

1. Workstations

2. Mainframe computers

3. Super computers

4. Mini computers

5. Personal computers

6. Microchip technology

7. Artificial Intelligences

8. Software Technology

9. Computerized documentation system/integrated set of information system".

\section{Communication Technology: -}

"Communication or telecommunication technologies are used to transmit information in the form of signals between remote locations, using electrical or electromagnetic media as carries of signals.

Communication technologies comprise the following: -

1. Audio technology - Audio-visual technology

2. Motion picture

3. Videodisc - Videotext

4. Teletext -

5. Telephone - Mobile phone

6. Facsimile transmission -

7. E-mail - Mail

8. Teleconference -

9. Internet

10. Network technology

11. Wide Area Network

12. Local Area Network

13. Satellite technology

\section{Reproduction Technology: -}

1. Reprographic technology

2. Micrographic technology

3. Printing technology" 


\section{ICT Needed in Libraries: Why}

"In terms of various problem faced but the traditional library systems.

The manual performance of library functions was getting difficult because of these main reasons.

Mushroom growth of recorded knowledge: -

No library can think of getting additional space every year, the collection will grow continuously.

Library operations:

Due to growth of information could take many hours to performs their routine operational work through conventional methods.

1. Due to information Developments

2. all sort of housekeeping operations can be performed by manual methods with less effective and reduce the accuracy." ( Chowdhury,2003)

\section{Services Provided by computer and related technologies:-}

"The advantages of using computers and other telecommunication devices in handling libraries are manifold. Some of the benefits are as follows:

Speed: -

A computer can carry out an instruction in less than a millionth of instants. Searching of information, compilation of bibliographical record, indexing and sorting can be process by computer in a few hours.

\section{Storage: -}

Human can store pieces of information to some confines whereas due to help of technology we can store bulk amount of data.

Accuracy: -

With the help of technology LIS Professionals Perform Functions very accurately.

\section{Repetitiveness: -}

Computer can be used repetitively to process information.

\section{Compactness: -}

The present-day computers are laptop, Tablet which do not occupy more space." (Nasiruddin,2002)

\section{Functions and Benefits of ICT Based Library system: -}

"ICT is used in various fields of library activities. Some of the areas where new technologies can perfectly be used are as follows:

\section{Acquisitions: -}

1. Acquisition of materials / Accession list

2. Ordering / report generating

3. Serials management:

4. Serials checking

5. claiming

6. Compilation of union list of holdings

7. Cataloguing/classification:

8. Catalogue card/label production

9. Retrospective conservation

10. On-line catalogue 


\title{
Circulation:-
}

1. Issuing/Returns

2. Interlibrary Loan

3. Reservation

4. Overdues

5. Audio-Visual Management

6. Audio visual Acquisition/Cataloging

7. Management

8. Accounting/Budgeting

9. Word Processing/Mailing

10. Planning

11. Reporting/Statistics

\section{Information storage and retrieval}

1. Database construction

2. Online database searching

3. Indexing/abstracting

\section{Reference information service.}

1. Bibliographic Compilation

2. Library Instruction

3. Public Access and Computer Literacy" (Siddique,1999)

\section{Technology Based user services: -}

Some library user is adopting electronic habits, making increasing use of the new ICT including: computers, the Intranet, Extranet and other technologies. As a result, library users are placing new demands on their libraries. "They require access to the latest information, updated information resources and access to ICT facilities that they could use in their work.

Use of ICT in libraries enhances user's satisfaction. It provides numerous benefits to library users.

\section{Some of the benefits are:}

1. Provide speedy and easy access to information

2. Provides remote access to users

3. Provides round the clock access to users

4. Provides access to unlimited information from different sources Provides information flexibility to be used by any individual according to his/her requirements Provides increased flexibility, Facilitates the reformatting and combining of data from different sources.

\author{
Libraries are also providing various, ICT-based services to their users, including the following: - \\ Provision of Web access to OPACs \\ Electronic document delivery \\ Networked information resources \\ Delivery of information to user desktops \\ Online instructions \\ Web access to OPACs. \\ Libraries and information center are providing access to web- based online public access catalogue \\ (OPAC)interface." (Igwe, 2010).
}

\section{Electronic document delivery: -}

Library and information center are implementing ICT-Based Interlibrary lending system using electronic networks to deliver copies of journal articles and other documents in digital format (PDF)to library user desktop.

Network information Resources:

Libraries are providing their patrons with access to networked information resources. Databases, E-Journals etc. 


\section{ICT in Libraries: Various Challenges:-}

1. The use of ICT in libraries has raised a number of challenges:

2. Changing role of libraries and librarians

3. Funding for libraries

4. Copyright management

5. Information access

6. Preservation of digital information resources

Impact of Information communication technology on Libraries and Library Professionals: -

"Computer has brought in a new impact to the library and information usage .in libraries, information technology has assisted library professional to provide value-added quality information services and give more remote access to globally available information resources." (Saraf,1998). "Modern ICT is impacting on various aspects of libraries and the information profession. Advancement in ICT and the wide spread use of ICT is Resulting in digital information sources and digital media replacing and becoming a leading form of information storage and retrieval.”(Sharifulislam and NazmulIslam, 2006)

"The term library no longer refers only to physical building located in a specific geographical location but also to electronic or digital or virtual libraries that can be access from anywhere.

Access to digital information resources is not restricted to specific hours and days of the week at one physical library building.

ICT with its spectacular information sources rapid transmissions speed and easy access ensure the satisfaction of the user with complex demand. Break down the geographical distance and boundaries and shortened the time required and ensure the information According to Ranganathan Law "provide right information to right user at the right time".it is really an excellent tool for th library and information centers."(chisenga,2004).

\section{Competencies and Challenges in a New Environment: -}

"Libraries make up an essential part of an institution or organization. As the scientific and technological development impacts the educational systems, it has shown a great influence on all types of library and their services, too. With major evolution in a number of segments of societies, public libraries are also opting for digital options to improve their operations and facilities.

If the standards in higher education are to be raised, the standard of our libraries needs to be raised and become more serviceable to help the changing current trends of higher education, research and teaching techniques." ( Rastogi,1989)

The patterns of library services have changed due to these technological developments such as latest electronic processing and disseminations of information. The new environment provides speed and accuracy in library services. New formats are being introduced for information storage and retrieval. As a result of the adoptions of latest technology, libraries are now able to provide quick and better services to their users. "The all types of libraries are embracing digital collection, although most libraries will continue to offer both print and digital collections for many years to come. New purchases and purchases of journals, magazines and abstracting and indexing services are heavily weighted towards digital, while digital books are only beginning to become a present library collection. Libraries prefer digital resources for many reasons such as digital collection save the space and are relatively easy to maintain." (Khan and Ahmed,1998.)

"The emergence of IT is one of the wonderful gifts of modern science and technology, which has brought tremendous changes in Library and Information Science. It has opened up a new chapter in library communication and facilitated global access to information crossing the geographical limitations." (SharifulIslam and NazmuIslam,2006).“Using ICT, libraries are also playing a very important role in facilitating access to global information and knowledge resources.”(Rowley \& Lea,1987).

"Information, as the saying goes, is power. The primary objective of libraries is to organize and provide access to information. This objective will never change, although the formal methods used can changed dramatically, providing new opportunities and challenge." (Anwer,1992) 
As these modern developments provide countless facilities to libraries, they also pose some challenges. For instance, the collection development, selection of materials and certain other tasks of library have become complicated due to the explosion of information.

On the other hand, the responsibilities and duties of library professionals have expanded. Despite this, nevertheless, they can now work more efficiently and conveniently in the provision of a required piece of information with the help of information technology. At the same time, it is also deemed necessary that a library collects the latest information present in different formats to support the current educational and research trends.

The changing operative dimensions in libraries, today, call not only for automated services but also for a change in their traditional role from being a warehouse of books into effective service libraries. Thus, we can say that it is the requirement of all libraries to adopt latest technology to compete with the other departments within an organization.

\section{Conclusion: -}

The explosive nature of development in information and communication technologies are influencing and reshaping the working patterns of all types of libraries in this new era .change in computer technology and consortia concept in developed world is not realized and followed as in developing world .concept of globalization and localization made a provision to developing countries to join the race of survival in technological world.

\section{References: -}

1. Adams, Roy J. Information Technology and libraries a further for academic libraries. London: Croom Helen, 1986. p. 17

2. Anwer, Mumtaz A. (1992). Use of information technology in the libraries of Pakistan.PLB.xxii(4):1

3. Chisenga, J. (2004). ICT in libraries :an overview and general introduction to ICT in libraries in Africa paper presented at INASP ICT workshop held at Johannesburg. South Africa on 21-23 July.

4. Chowdhury, C.G., Chowdhury, Introduction to digital libraries, pp. 284-292. Facet Publishing, London (2003).

5. Daniel Bell, http://www.brainquote.com/quotes/d/danielbell177480.html Retrieved March 15,2019.

6. Islam, Md Shariful and Islam,Nazmul.(2006).Information and communication technology (ICT):A new dimension in librarianship.Asia.J.Inf.Tech.5(8):809-817

7. Khan, Najaf Ali. 1995. Information Technology in the University Libraries of Pakistan Stresses and Strains. PLB. xxvi (1):1.4

8. Khan, M.S.I. Electronic communication and information dissemination. In: Lecture delivered in the workshop on Population Information Network, IEM/BCC unit, Dhaka (October 29, 2000).

9. Khan, M.Fazil and Amed,Pervaiz.(1998).University library services in Pakistan: A survey.Pak.Lib \&Inf.Sci.J.38(1):3

10. Nasiruddin and M, Roknuzzaman. (2002). Technological influence on library environment contemporary challenges for the Professionals' of Bangladesh, Raj Shahi University studies. part c.10,

11. Pradhan, M.R. (2004). Developing digital libraries technologies and challenges. Lib.Herald, New Delhi,42:100

12. Patil, D.B.,S.S.Kumbarand and H Krishnananda.(1994).Information Technology current trends in library and information science, $32 \mathrm{p}$.

13. Rahman, S. (2003). An overview of ICT sector in Bangladesh. Paper presented at FOBANA 2003 Convention, Washington, DC, http://www.banglait.org/ICTBANGLADESH.pdf

14. Rowley, J. E and P, Lea. (1987). Infotech. A guide for young professional libraries. London.Rempty,23-29

15. Siddique, Moid.A.(1992). The use of information technology in academic libraries in Saudi Arabia. J. of libr. and inf. Sci. 29(4):195

16. Sehar, Naveed. (2017). Need and importance of library automation and networking in public libraries of Karachi, Pakistan.AJMS.5(7):182-189

17. Toffler, Alvin. (1970). http://www.physics.udel.edu/watoson/scan103/quates.html Retrieved.March,19,2019 